\title{
Інноваційні технології в хірургічному лікуванні злукової непрохідності кишечника на тлі хвороби очеревини
}

\begin{abstract}
Мета роботи: покращити результати хірургічного лікування пацієнтів із післяопераційною злуковою непрохідністю кишечника на тлі спайкової хвороби очеревини за допомогою різних методів адгезеолізису. У клінічних хірургічних відділеннях кафедри хірургічних хвороб № 1 (КМКЛ №1) проведено аналіз хірургічного лікування 314 пацієнтів 3 післяопераційною злуковою хворобою.
\end{abstract}

Ключові слова: злукова хвороба; непрохідність.

Злукова хвороба очеревини виникла з появою оперативних втручань та буде мати місце в подальшому. Вперше злукову хворобу в 1783 році описав англійский хірург Дж. Пунтер у своїй роботі “Кров, запалення та вогнепальні рани”. Він перший вказав на наявність клейковини (фібрин), яка склеює петлі кишечника.

За даними літератури, в різні періоди до злукового процесу ставлення по-різному, але ніколи не залишали це явище поза увагою. За даними міжнародної організації (International Adhesion Society), яка вивчає проблеми, пов’язані зі злуковим процесом в черевній порожнині, післяопераційний злуковий процес - це найчастіше ускладнення, яке виявляється в оперованих пацієнтів. У США, де злукову хворобу не виділяють за самостійну нозологію щорічно виявляють до 300000 тисяч хворих, а затрати на лікування перевищують 1 млрд доларів США (International Adhesion Society). Впродовж останніх років за даними різних авторів, післяопераційні спайкоутворення виявляють у 7093 \% хворих, які перенесли порожнинні операції $[1,2]$. Злукова хвороба достатньо часто ускладнюється гострою злуковою кишковою непрохідністю (ГЗКН). Частка пацієнтів із ГЗКН в хірургічному стаціонарі становить близько 3,5 \%, а в структурі непрохідності кишечника до 87,6 \% [3]. В тих же спостереженнях вказано, що найчастішими учасниками внутрішньочеревних спайок були зрощення великого сальника з післяопераційним рубцем на черевній стінці у 53,3 \% та зі сліпою у 33,3 \%, а також плівчасті спайки в правому бічному каналі у 45,3 \%. У 2001 році в США було зареєстровано близько 2200 смертей від ускладнень, пов’язаних із злуковою кишковою непрохідністю. За даними (Wiseman D.M., 2006) кількість жінок становить 60 \%, від загальної кількості. Кожен другий пацієнт, після лікуванні злукової хвороби очеревини (ЗХО) має рецедив (Вербицький Д.А., 2004; Матвеев Н.Л., 2007). Вдосконалення хірургічного інструмента, обладнання, нових технічних аспектів виконання оператиного лікування не призводить до зниження частоти виникнення $3 \mathrm{XO}$ та ГЗКН [4].

Виходячи з протоколу МОЗ України “Уніфікований клінічний протокол вторинної (спеціалізованої) медичної допомоги” (2016) в Україні частота гострої кишкової непрохідності становить приблизно 5:100000 населення, а відносно до ургентних хірургічних хворих - до 5 \%. У той же час за летальними наслідками в абсолютних цифрах ця патологія займає одне з перших місць серед всіх гострих захворювань органів черевної порожнини [5, 6, 7-12].

Таким чином, незважаючи на науково-технічний прогрес і до сьогодні злукова непрохідність кишечника та її ускладнення (заворот, некроз та перитоніт) є актуальною проблемою для сучасної хірургіï.

Mета роботи: покращити результати хірургічного лікування пацієнтів із післяопераційною злуковою непрохідністю кишечника на тлі спайкової хвороби очеревини за допомогою різних методів адгезеолізису.

У клінічних хірургічних відділеннях кафедри хірургічних хвороб № 1 (КМКЛ № 1) впродовж 2006-2016 рр. проведено аналіз хірургічного лікування 314 пацієнтів з післяопераційною злуковою хворобою. Вік пацієнтів варіював від 20 до 70 років. Пацієнтів чоловічої статі було 115 (36,62 \%), жіночої - 209 (63,38 \%). Внаслідок запальних процесів - 72 (29,92 \%); внаслідок перфорації порожнистих органів черевної порожнини 53 (16,88 \%); внаслідок травматичних ушкоджень 
черевної порожнини - 27 (8,6 \%); внаслідок інших оперативних втручань на органах черевної порожнини - 162 (51,6 \%). У даному випадку основною причиною післяопераційної злукової хвороби було оперативне лікування, проведене на органах малого таза та хробакоподібному відростку. При госпіталізації хворим проводили додаткові методи обстеження: 1) загальноклінічні аналізи крові та сечі, біохімічний аналіз крові, коагулограма, група крові та резус-фактор; 2) ультразвукове обстеження органів черевної порожнини та малого таза; 3) рентгенологічне обстеження органів черевної порожнини; 4) комп’ютерна томографія органів черевної порожнини та малого таза; 5) обстеження контрастними речовинами (пасаж барія); клінічне спостереження.

За період з 2006 по 2019 рр. для лікування злукового процесу використовували різні методи, інструменти та обладнання для подальшого дослідження, які були поділені на дві основні групи:

1. Основна група - 151 (48,09 \%) пацієнт, оперований за допомогою новітніх технологій, а саме електрообладнання (моно- та біполярна коагуляція, ультразвуковий скальпель (Harmonic); апарат для зварювання (LigaSure); гідроструйний дисектор.

2. Контрольна група - 163 (51,91 \%) пацієнтів, яким застосовували інші методи адгезіолізису, такі як гостре розсічення злуки за допомогою ножиць; тупого розривання спайки.

В основній групі, пацієнтів чоловічої статі було 48 (37,79 \%) та жіночої статі - 103 (68,21 \%).

При використанні таких електроприладів при адгезіолізисі, як Liga Sure (Covidien), моно- та біполярна коагуляція можна відзначити ефективність, але дія даних приладів на тканини органів черевної порожнини є патогенною. При виникненні високих температур з'являються контактні поля враження струмом, які викликають ефект обвуглення (опіку) тканин. Останнє призводить до згортання білка та утворення запального процесу, в місці контакту, внаслідок якого в подальшому виникає ризик злукоутворення. Група пацієнтів налічує 80 осіб, що становить 52,98 \% від обстежуваної кількості. Післяопераційні ускладнення виникли в 9 пацієнтів, що дорінює 100 \% від цієї групи. Це пов'язано з ятрогенними пошкодженнями та запальними процесами в черевній порожнині. При використанні скальпель (Harmonic) має переваги над традиційними електролігуючими інструментами, тому що дає нам можливість швидше виконувати адгезіолізис, ергономіка ручки дає додаткові переваги та одномоментно маємо кращу якість гемостазу. Ще однією перевагою ультразвукового скальпеля над традиційними електрохірургічними пристроями набагато меншим латеральним термічним пошкодженням тканин, що дозволяє безпечно використовувати даний пристрій поблизу великих судин. Також спостерігається менша кількість диму при роботі, проходження електротоку через тіло та нейром'язової стимуляції. Дана методика дуже добре зарекомендувала себе при виконанні лапароскопічних методів адгезіолізису. При використанні гідродисекції практично відсутня крововтрата, тому що струмінь рідини, який діє на тканину, не ріже останню, а розсуває, при цьому не травмує судинні структури. Швидкість та зручність використання гідродисекції дозволяє в рази скоротити час на адгезіолізис. Використання антисептичних розчинів дає можливість зменшити бактеріальну складову, це і є запорукою зменшення запальних процесів, мінімізації ятрогенних ушкоджень і післяопераційних ускладнень. Таких пацієнтів було 71, що становило 47,02 \% досліджуваної групи. В даній групі пацієнтів ускладнень не виявлено. Використання таких методів, як гостре розсікання злук ножицями, тупе розривання прискорює процес розлучення зпайок, але водночас поступається, оскільки, як правило, має велику кількість ускладнень (ятрогенні пошкодження органів черевної порожнини, ушкодження судин та нервів, більша кількість післяопераційних ускладнень). В контрольній групі кількість ускладнень складає 9 (2,87 \%) випадків та в більшості пов'язані з інтраопераційною ятрогенією.

Таким чином, при обговоренні даних результатів групою авторів, ми можемо сказати, що дана проблема гостро відображається на роботі хірургічного стаціонара та має велику актуальність на сьогодні. Використання інноваційних технологій покращує результати роботи, але не дає повної впевненості в тому, що в післяопераційному періоді пацієнт не повернеться в хірургічний стаціонар зі злуковою хворобою очеревини, яка негативно впливає на соматичний стан, а і ще може мати ускладнення у вигляді кишкової непрохідності.

Використання новітніх методик в лікуванні злукової хвороби та ії̈ ускладень має велику роль в житті хірургічних стаціонарів. Всі методи мають право на життя, але високотехнологічні, як показує наш досвід, мають перевагу. Також не можливо залишити поза увагою економічну складову даного питанні, не всі клініки нашої країни у своїй практиці мають змогу використовувати вартісне обладнання, що і призводить до повторних злукоутворень та їх ускладнення. На прикладі нашого досвіду використання таких інструментів, як скальпель (Harmonic) дає непогані результати лі- 


\section{ПОВІДОМЛЕННЯ}

кування, але висока ціна на утримання та витратні матеріали не дає можливості використовувати його більш широко в практиці хірургічних стаціонарів. Використання гідродисекції як методу адгезіолізису менш травматичне для органів черевної порожнини, зменшує кількість крововтрати при операції, прискорює час операції та зводить на нівець кількість післяопераційних ускладнень, має економічні переваги. Це є запорукою успіху в лікуванні даної патології.

\section{СПИСОК ЛІТЕРАТУРИ}

1. Хасанов А. Г. Способ хирургического лечения и профилактики послеоперационных перитонеальных спаек / А. Г. Хасанов, И. Ф. Суфриянов, С. С. Нигматзянов // Хирургия. 2008 - № 3. - С. 43-45.

2. Этапный лапароскопический адгезиолизис с применением противоспаечных барьерных средств / И. В. Михин, А. Г. Бебуришвили, А. Н. Акичиц, П. Б. Кремер // Эндоскопическая хирургия. - 2010. - № 1. - С. 20-24.

3. Лубянский В. Г. Эффективность лечения конгломератных форм спаечной кишечной непроходимости с применением еюнотрансверзоанастомоза / В. Г. Лубянский, И. Б. Комлев // Хирургия. - 2009. - № 3. - С. 29-32.

4. Антиангинальная терапия и спаечный процесс в малом тазу: перспективы профилактики и лечения / В. А. Бурлев, Е. Д. Дубинская, А. С. Гаспаров, Н. А. Ильясова // Российский вестник акушера-гинеколога. - 2010. - № 4, Т. 10. - С. 25-31.

5. http://www.moz.gov.ua:

6. http://www.dec.gov.ua/mtd/reestr.html

7. Brian Nobie A. Small-bowel obstruction treatment \& management / Brian A. Nobie. - 2013.

\section{REFERENCES}

1. Khasanov, A.G., Sufriyanov, I.F., \& Nigmatzyanova, S.S. (2008). Sposob khirurgicheskogo lecheniya i profilaktiki posleoperatsionnykh peritonealnykh spayek [The method of surgical treatment and prevention of postoperative peritoneal adhesions]. Khirurgiya - Surgery, 3, 43-45 [in Russian].

2. Mikhin, I.V., Beburishvily, A., Akichits, A.N., Kremer, P.B. (2010). Etapnyy laparoskopicheskiy adgeziolizis s primeneniyem protivospayechnykh baryernykh sredstv [Stage laparoscopic adhesiolysis with the use of anti-adhesivebarriers]. Endoskopicheskaya khirurgiya - Endoscopic Surgery, 1, 20-24 [in Russian].

3. Lubyanskiy, V.G., \& Komlev, I.B. (2009). Effektivnost lecheniya konglomeratnykh form spayechnoy kishechnoy neprokhodimosti s primeneniyem eyunotransverzoanastomoza [The effectiveness of the treatment of conglomerate forms of adhesive intestinal obstruction with the use of junotransverse anastomosis]. Khirurgiya - Surgery, 3, 29-32 [in Russian].

4. Burlev, V.A., Dubinskaya, Ye.D., Gasparov, A.S., \& Ilyasova, N.A. (2010). Antianginalnaya terapiya i spayechnyy protsess v malom tazu: perspektivy profilaktiki i lecheniya [Antianginal therapy and adhesions in the pelvis: prospects for prevention and treatment]. Rossiyskiy vestnik akushera-ginekologa - Russian Bulletin of the Obstetrician-Gynecologist, 4, 25-31 [in Russian].

5. http://www.moz.gov.ua:

6. http://www.dec.gov.ua/mtd/reestr.html

7. Brian Nobie, A. (2013). Small-bowel obstruction treatment \& management.
8. Attard Jo-Anne P. Adhesive small bowel obstruction: epidemiology, biology and prevention / P. Attard Jo-Anne, A. R. MacLean // Can. J. Surg. - 2007. - Vol. 50 (4). - P. 291-300 9. Gutt C. N. Fewer adhesions after laparascopic surgery / C. N. Gutt, T. Oniu // Surg. Endosc. and Intervent. Techn. - 2004. - Vol. 18. - P. 898-906.

10. Wiseman D. M. Disorders of adhesions or adhesion-related disorder: monolithic entities or part of something bigger CAPPS? / D. M. Wiseman // Semin. Reprod. Med. - 2008. Vol. 26 (4). - P. 356-368. doi: 10.1055/s-0028-1082394.

11. Результаты применения 4 \% раствора икодекстрина для профилактики спаечного процесса после хирургических и гинекологических операций / Н. Л. Матвеев, Д. Ю. Арутюнян, Н. Л. Матвеев, М. А. Дигаева // Эндоскопическая хирургия. 2008. - № 3. - С. 45-54.

12. Гідроструменеві технології в медицині - скальпель гідроструменевий / В. М. Бадах, В. П. Бочаров, В. В. Скиба [та ін.] // Збірник тез доповідей Міжнародної науково-технічної інтернет-конференції “Гідро- та пневмоприводи машин - сучасні досягнення та застосування”, Вінниця, 27-29 грудня, 2018 р. - Вінниця, 2018. - С. 7-8.

8. Attard Jo-Anne P., \& MacLean, A.R. (2007). Adhesive small bowel obstruction: epidemiology, biology and prevention. Can. J. Surg., 50 (4), 291-300 [in Russian].

9. Gutt, C.N., \& Oniu, T. (2004). Fewer adhesions after laparascopic surgery. Surg. Endosc. and Intervent. Techn., 18, 898-906 [in Russian].

10. Wiseman, D.M. (2008). Disorders of adhesions or adhesionrelated disorder: monolithic entities or part of something bigger - CAPPS? Semin. Reprod. Med., 26 (4), 356-368. doi: 10.1055 / s-0028-1082394. [In Russian].

11. Matveyev, N.L., Arutyunyan, D.Yu., Matveyev, N.L., \& Digayeva, M.A. (2008). Rezultaty primeneniya $4 \%$ rastvora ikodekstrina dlya profilaktiki spayechnogo protsessa posle khirurgicheskikh i ginekologicheskiy operatsiy [The results of the use of $4 \%$ icodextrin solution for the prevention of adhesions after surgical and gynecological operations]. Endoskopicheskaya khirurgiya - Endoscopic Surgery, 3, 45-54 [in Russian].

12. Badakh, V.M., Bocharov, V.P., \& Skyba, V.V. (2018). Hidrostrumenevi tekhnolohii $\mathrm{v}$ medytsyni - scalpel hidrostrumenevyi [Hydrostrum technology in medicine - scalpel]. Zbirnyk tez dopovidei Mizhnarodnoi naukovo-tekhnchnoi internetkonferentsii "Hodro- ta pnevmopryvody mashyn - suchasni dosiahnennia ta zastosuvannia - Proceedings of the International Scientific and Technical Internet Conference "Hydraulic and Pneumatic Drives of Machines - Modern Achievements and Applications”. Vinnytsia, December, 27-29 [in Ukrainian]. 
V. V. SKIBA, O. V. IVANKO, V. F. RYBALCHENKO, V. V. LYSYTSIA, DAR YASSIN AHMED

Kyiv Medical University

O. Bohomolets National Medical University, Kyiv

\section{INNOVATIVE TECHNOLOGIES IN SURGICAL TREATMENT OF ADHESIVE BOWEL OBSTRUCTION ON THE BACKGROUND OF PERITONEUM DISEASE}

The aim of the work: to improve the results of surgical treatment of patients with postoperative adhesive bowel obstruction on the background of adhesive disease of the peritoneum, using various methods of adhesiolysis. The analysis of surgical treatment of 314 patients with postoperative peritoneal commissures was performed in the Clinical Surgical Departments of the Department of Surgical Diseases No. 1 (Kyiv City Clinical Hospital No. 1).

Key words: peritoneal commissures, obstruction.

В. В. СКИБА, А. В. ИВАНЬКО, В. Ф. РЫБАЛЬЧЕНКО, В. В. ЛИСИЦА, ДАР ЯСИНЯ АХМЕД

ЧВУз “Киевский медицинский университет”, Киев

Национальный медицинский университет имени А. А. Богомольца, Киев

\section{ИННОВАЦИОННЫЕ ТЕХНОЛОГИИ В ХИРУРГИЧЕСКОМ ЛЕЧЕНИИ СПАЕЧНОЙ НЕПРОХОДИМОСТИ КИШЕЧНИКА НА ФОНЕ БОЛЕЗНИ БРЮНИНЫ}

\footnotetext{
Цель работы: улучшить результаты хирургического лечения пациентов с послеоперационной спаечной непроходимостью кишечника на фоне спаечной болезни брюшины с помощью различных методов адгезиолизиса. В клинических хирургических отделениях кафедры хирургических болезней № 1 (КГКБ № 1) проведен анализ хирургического лечения 314 пациентов с послеоперационной спаечной болезнью.
}

Ключевые слова: спаечная болезнь; непроходимость. 